\title{
Species Diversity and Abundance of Birds along Boat Touring Routes for Ecotourism in Tha-kha Sub-District, Amphawa District, Samut Songkram Province, Thailand ${ }^{+}$
}

\author{
Nitinarth Charoenpokaraj ${ }^{1, *}$ and Petchpanom Chitman ${ }^{2}$ \\ 1 Faculty of Science and Technology, Suan Sunandha Rajabhat University, 1 U-thong Nok Road, \\ Dusit District, Bangkok 10300, Thailand \\ 2 Demonstration School of Suan Sunandha Rajabhat University, 1 U-thong Nok Road, Dusit District, \\ Bangkok 10300, Thailand; petchpanom.ch@ssru.ac.th \\ * Correspondence: nitinarth.ch@ssru.ac.th or niti718@hotmail.com; Tel.: +66-817-010-718 \\ + Presented at the Economy, Sustainable Development and Energy International Conference (ESDEIC), \\ Edinburgh, Scotland, UK, 25-27 June 2018.
}

Published: 5 November 2018

\begin{abstract}
Tha-kha Floating Market is a famous tourist attraction in Tha Kha sub-district, Amphawa district, Samut Songkram Province, Thailand. There are Thai paddle-boats for tourists to get close to nature and local people lifestyle along the canals. The objectives of this research were (1) to study species diversity, feeding behavior and status of birds in the research area. (2) to analyze abundance and similarity of birds in the research area. The data was carried out by field survey of species of birds and their behaviors sighted directly and from their calls by using line transect method then classify species, feeding behavior and status of birds, analyze their abundance and similarity in three routes. Three boat touring routes were surveyed; route 1 (Tha Kha floating market-homestay), route 2 (Tha Kha floating market-Thai traditional sugar making kiln), and route 3 (Thai traditional sugar making kiln-resort). The survey was conducted in the morning from 7 a.m. to 10 a.m. and in the afternoon from 3 p.m. to 6 p.m. One survey was made each month from April 2017-March 2018. The result of this research found that there were 15 orders, 37 families and 74 species of birds. The highest number of bird species in 3 routes was 49 species in December and 47 species in November accordingly because it was migratory season of migratory birds in the research area. According to bird feeding behavior, the maximum insectivorous bird species of 35 were found in 3 routes. According to status of birds, 52 resident birds, 9 migratory birds, 13 resident and migratory birds were found in 3 routes. According to bird abundance, 21 bird species were in level 5, 7 bird species in level 4, 20 bird species in level 3, 9 bird species in level 2 and 17 bird species in level 1 . According to bird similarity index, the similarity index between route 1 and route 3 was 0.814 . The community also organized eco-touring activities by using Thai paddle-boats. So the birds are as indicators of natural balance of local ecosystem.
\end{abstract}

Keywords: species diversity of birds; abundance of birds; boat touring routes

\section{Introduction}

Samut Songkram Province is a small province, located at central region of Thailand near the mouth of the Mae klong River and along the Inner Gulf of Thailand. Tha-kha is a small sub-district in Amphawa District, Samut Songkram Province. The most attractive tourist sites are the Tha-ka floating market, Thai traditional coconut sugar making kiln, the home-style method of producing 
coconut sugar, watching the fireflies and local people lifestyle along the canals. The riverine flora along the canal were also the habitat of many kinds of birds such as Little Egret, Collared Kingfisher, Brahminy Kite, Streak-eared Bulbul and so on [1].

There were coconut orchards near the canal which were foraging site for both resident and migratory birds. So, the researchers were interested in studying species diversity and abundance of birds along boat touring routes for ecotourism in Tha-kha Sub-district, Amphawa District, Samut Songkram Province, Thailand. The community also organized eco-touring activity by using Thai paddle-boats. So the birds are as indicators of natural balance of local ecosystem.

\section{Research Objectives}

(1) to study species diversity, feeding behavior and status of birds in the research area.

(2) to analyze the abundance and the similarity of birds in the research area.

\section{Research Methodology}

1. Area Study

Three boat touring routes were surveyed; route 1 (Tha Kha floating market-homestay), route 2 (Tha Kha floating market-Thai traditional coconut sugar making kiln), and route 3 (Thai traditional coconut sugar making kiln-resort), two-kilometer long per each route.

2. Data Collection and Analysis Method

Step 1: Survey the birds

Observe and survey the birds and their behaviors by using binoculars and camera then identified the birds as found according to the books "A Guide to the Birds of Thailand" [2], "A Field Guide to the Birds of Thailand and South-East Asia" [3]. The survey three along boat touring routes was conducted from 7 a.m.-10 a.m. and from 3 p.m.-6 p.m. The survey was made once a month from April 2017-March 2018. Record the species of birds and their behaviors sighted directly and from their calls by using line transect method.

Step 2: Classify the bird species, feeding behaviors and status of birds according to the checklist of Thai Birds by Bird Conservation Society of Thailand (2016)

Step 3: Analyze the abundance [4] and the similarity of birds [4]

Step 4: Conclusion and report the results

\section{Results}

The results found that 15 orders, 37 families and 74 species of birds were found in three boat touring routes. The maximum number of thirty-five species of birds in order Passeriformes was found. Ten orders, 28 families and 50 bird species were found in route 1. Eleven orders, 31 families and 55 bird species were found in route 2 . Thirteen orders, 34 families and 63 bird species were found in route 3 .

In August, the maximum number of bird species was in route 1 and route 2. In December, the maximum number of bird species was found in route 3 because it was migratory season of migratory birds in the research area, as shown in Figure 1.

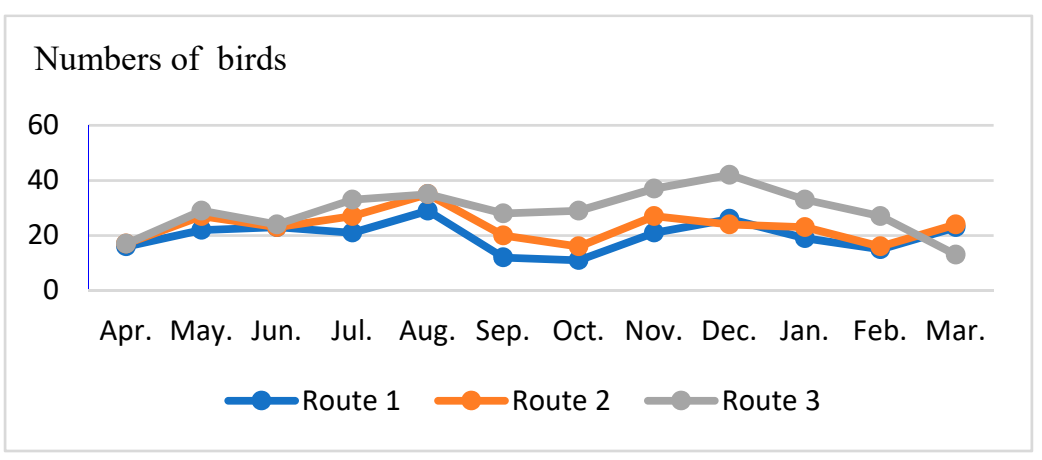

Figure 1. Bird species found in 3 boat touring routes, in Tha-kha Sub-district, Samut Songkram Province. 
In term of feeding behaviors, there were 35 species of insectivorous birds such as Taiga Flycatcher (Ficedula albicilla). There were 15 species of piscivorous birds such as Common Kingfisher (Alcedo atthis). There were 8 species of granivorous birds such as White-rumped Munia (Lonchura striata). There were 5 frugivorous birds such as Pink-necked Green pigeon (Treron vernans). There are 5 carnivorous birds such as Brown Shrike (Lanius cristatus). There are 4 species of omnivorous birds such as White-breasted Waterhen (Amaurornis phoenicurus). There are 2 species of nectarivorous birds namely; Olive-backed Sunbird (Cinnyris jugularis) and Brown-throated Sunbird (Anthreptes malacensis). The maximum insectivorous bird species were found in three boat touring routes.

As for the status of the birds in 3 routes, there were 52 resident birds, 13 resident and migratory birds, and 9 migratory birds. In route 1, there were 38 resident birds, 8 resident and migratory birds, and 4 migratory birds. In route 2, there were 46 resident birds, 4 resident and migratory birds, and 5 migratory birds. In route 3 , there were 45 resident birds, 10 resident and migratory birds, and 8 migratory birds.

As for migratory birds, Black-capped Kingfisher (Halcyon pileata) and Yellow-browed Leaf Warbler (Phylloscopus inornatus) were in 3 boat touring routes, as shown in Figures 2 and 3.

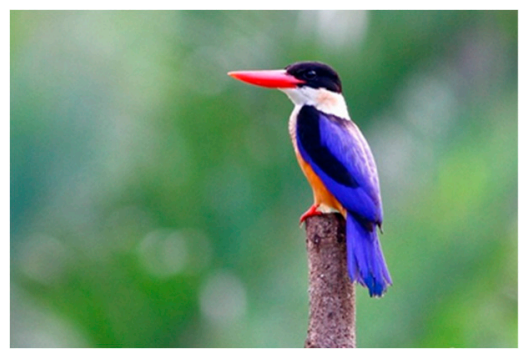

Figure 2. Black-capped Kingfisher.

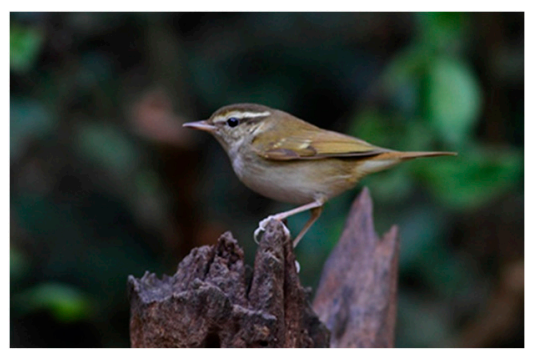

Figure 3. Yellow-browed Leaf Warbler.

The abundance of birds in 3 routes were grouped into five categories namely level 5 abundant, level 4 common, level 3 moderately common, level 2 uncommon and level 1 rare. Twenty-one bird species were in level 5. It was $28.38 \%$ of all bird species. Seven bird species were in level $4,9.46 \%$. Twenty bird species were in level 3,27.03\%. Nine bird species in level 2, 12.16\% and 17 bird species were in level 1, 22.97\%. The highest number of bird species in the research area was 49 species in December and 47 species in November accordingly because it was migratory season of migratory birds in the research area. Abundance of Birds in 3 boat touring routes was shown in Table 1.

Table 1. Species diversity of birds sighted in 3 boat touring routes each month, categorized by abundance from April 2017-March 2018.

\begin{tabular}{|c|c|c|c|c|c|c|c|c|c|c|c|c|c|c|}
\hline \multirow{2}{*}{$\begin{array}{c}\text { Abundance } \\
\text { Level }\end{array}$} & \multirow{2}{*}{$\begin{array}{c}\text { Number } \\
\text { of } \\
\text { Species }\end{array}$} & \multirow{2}{*}{$\begin{array}{c}\text { Percentage } \\
\text { of Number } \\
\text { of Bird } \\
\text { Species }\end{array}$} & \multicolumn{12}{|c|}{ Number of Bird Species Foraging in the Research Area in Each Month } \\
\hline & & & Apr. & May & Jul & Jun. & Aug & Sep. & Oct. & Nov & Dec & Jan. & Feb. & Mar. \\
\hline 5 & 21 & 28.28 & 20 & 21 & 19 & 21 & 21 & 21 & 20 & 21 & 21 & 21 & 17 & 20 \\
\hline 4 & 7 & 9.46 & 3 & 5 & 6 & 6 & 7 & 6 & 6 & 4 & 7 & 5 & 4 & 4 \\
\hline 3 & 20 & 27.03 & 5 & 8 & 3 & 6 & 11 & 5 & 5 & 17 & 16 & 10 & 7 & 9 \\
\hline Total & 74 & 100 & 30 & 37 & 29 & 35 & 46 & 32 & 35 & 47 & 49 & 41 & 31 & 34 \\
\hline
\end{tabular}


It was seen that the bird similarity index in route 1 and route 3 is 0.814 , showing that the number of bird species that foraged in both areas is very similar, because the environment of route 1 and route 3 is largely consists of coconuts orchards and riverine forests along the canal which are foraging area of many birds.

\section{Conclusions}

It was found that there were 15 orders, 37 families and 74 species of birds. According to their feeding behavior, there were 35 species of insectivorous birds, 15 species of piscivorous birds, 8 species of granivorous birds, 5 species of frugivorous birds, 5 species of carnivorous birds, 4 species of omnivorous birds and 2 species of nectivorous birds. As for the status of the birds, there were 52 resident birds, 13 resident and migratory birds, and 9 migratory birds. According to bird abundance, 21 bird species were in level 5, 7 bird species in level 4, 20 bird species level 3, 9 bird species in level 2 and 17 bird species in level 1 . According to bird similarity index, the similarity index between route 1 and route 3 was 0.814 .

\section{Discussion}

Tha-kha Floating Market is famous tourist place in Tha Kha sub-district, Amphawa district, Samut Songkram Province, Thailand. There are Thai paddle-boats for tourist to get close to local people lifestyle such as Thai traditional coconut sugar making kiln, the home-style method of producing coconut sugar and do sight-seeing nature such as watching fireflies, birds along three boat touring routes. The results found that 15 orders, 37 families and 74 species of birds were found in the research three boat touring routes. There were 9 migratory birds such as Common Kingfisher (Alcedo atthis), Black-capped Kingfisher (Halcyon pileata), Yellow-browed Leaf Warbler (Phylloscopus inornatus), Black-eared Kite (Milvus lineatus). In the nature trail at Bang Kaew Sub-district, 31 migratory bird species such as Black-capped Kingfisher (Halcyon pileata), Common Kingfisher (Alcedo atthis) were found [5]. So the birds are as indicators of natural balance in local ecosystem. Because the birds are of value to the environment in regards to pollination, spreading plant seeds and destroying harmful crop bugs. So the community should be supported in keeping the canals clean, and the fruit farmers should be supported in using organic techniques in order to conserve the diversity of birds and arrange ecotours along the boat touring routes. It is related to Chutchat [5] who said that ecotourism is to get a chance to get close and experience the nature and local people's life style and acknowledge the value of resources and offers a job and income to local people.

Author Contributions: N.P. and P.C. conceived and designed the experiments, analyzed the data and wrote the paper. N.P. and P.C. performed the experiment.

Acknowledgments: The authors wish to acknowledge the support and founding of this research by Suan Sunandha Rajabhat University, Bangkok, Thailand.

Conflicts of Interest: The authors declare no conflict of interests.

\section{References}

1. Weera Thepkorn. Canal-Side Forests: Sibling Forests with Mangrove Forests; Aksorn Charoentat: Bangkok, Thailand, 2006.

2. Lekagul, B.; Round, P.D. A Guide to the Birds of Thailand; Sahakarn Bhaet Press: Bangkok, Thailand, 1991.

3. Robson, C. A Field Guide the Birds of Thailand and South-East Asia; Asia Book Co., Ltd.: Bangkok, Thailand, 2008.

4. Odum, E.P. Basic Ecology; Holt-Saunders: Tokyo, Japan, 1983.

5. Chuchat, C. Forms of Eco-Tourism in the Waang River Watershed; Nor. Por. Phor.: Chiang Mai, Thailand, 2001.

6. Pettingill, O.S. A Laboratory and Field Manual of Ornithology; Burgess Publication Company: Minneapolis, MN, USA, 1969. 
7. Plailek, W.; Chitman, P.; Charoenpokaraj, N. Species Diversity of Birds in the Mangrove Nature Trail, Bang Kaew Sub-District, Muang District, Samut Songkhram Province; Suan Sunandha Rajabhat University: Bangkok, Thailand, 2016.

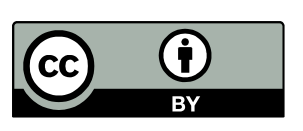

(C) 2018 by the authors. Licensee MDPI, Basel, Switzerland. This article is an open access article distributed under the terms and conditions of the Creative Commons Attribution (CC BY) license (http://creativecommons.org/licenses/by/4.0/). 